\title{
ANZAC after 100 years
}

\section{It is the hope \\ of a better \\ future, of \\ helping and of \\ being helped \\ to shape \\ that future \\ that most \\ inspires and \\ strengthens \\ hope}

harles Bean was Australia's official First World War historian. He landed with the Australian troops at Gallipoli on 25 April 1915 and remained with them at the front through the entire war. Wounded himself at Gallipoli, he wrote and edited the 12-volume official history of World War I over almost a quarter of a century. ${ }^{1}$

At its very end, presented with the task of summarising it all - 62000 dead and 155000 wounded of the 330000 soldiers who embarked for overseas, drawn from a nation that twice rejected conscription - Bean wrote: 1

What these men did, nothing can alter now.

The good and the bad, the greatness and the smallness of their story

It rises ... it always rises, above the mists of ages

A monument to great hearted men, and for their nation - a possession forever.

\section{The birth of Australia as a nation}

The great 19th century English philosopher John Stuart Mill wrote that there are two essential prerequisites for a nation to exist. The first was that a people would want to be governed as one. Late in the 19th century, decades of debate delivered the Commonwealth of Australia in 1901. The second was what Mill described as a "common fellow feeling", deeply rooted in language, literature and history.

Beyond its rich Indigenous history, the pioneering struggles of those who came on the First Fleet and those of others who joined them throughout the 19th century, it was the cataclysm that unfolded a century ago that gave us our story as Australians.

Every nation has its story. This is ours.

Australians were recruited into the Australian Imperial Force (AIF) and sent overseas in an Australian uniform with an Australian flag. The often tragic military battles that ensued, emergent deep divisions especially around the conscription referenda, the pride of victory infused with a generation of inconsolable grief and mourning - all combined to give our young nation a greater common belief in itself and its place in the world.

We emerged with a greater sense of being Australian.

It is tempting, human beings that we are, to settle for the broad brushstrokes of history. But we should not ever forget, through neglectful indifference, the devotion and countless individual sacrifices made in our name. To do so would diminish us and that for which we stand.

\section{Doctors on the battlefield}

A total of 1242 Australian Army Medical Officers, including 15 women, embarked with the 1st AIF. The four Aspinall brothers were among them.
A University of Sydney graduate, William Robert Aspinall MC joined the AIF in January 1916, after having completed his residency at Sydney Hospital. Aspinall was sent to Cairo, but was subsequently evacuated to London suffering pneumonia. Later in 1916, he joined the fighting on the Western Front in France. At Lagnicourt in April the following year, he was awarded the Military Cross. Surrounded by the enemy and under heavy fire, Aspinall went forward with the advancing troops of the 9th Battalion mounting a counterattack. He attended the wounded under fire as they fell, dragging them into shell holes and behind any cover until stretcher bearers could get to them. He was killed by a shell at Ypres in July 1917 and is buried in the Reninghelst New Military Cemetery near Poperinge, Belgium. He was 24 years old - one of 68 doctors listed on the Australian War Memorial's Roll of Honour.

William Aspinall - like each of us - had only one life, one chance to use life in a way that might serve others and our nation.

He chose medicine. He chose us.

\section{The ANZAC legacy of service to others}

In the end, ANZAC is the story of love and friendship. In their last moments, our soldiers died not only for country, but primarily for one another. The legacy they leave us is known as "mateship". ANZAC is the story of being prepared to serve the interests of other human beings ahead of our own, even at risk to our own lives. It is this commitment to an ethic of service to others that is also the fundamental tenet upon which the medical profession is built.

There is a great paradox here, that the most fragile, yet powerful, of human emotions is hope.

It is the hope of a better future, of helping and of being helped to shape that future that most inspires and strengthens hope.

Over the period in which we commemorate the centenary of the First World War, let us inspire the next generation to embrace the world as hopeful, confident, compassionate people, imbued with the ANZAC legacy of endurance, courage and a selfless determination to help one another.

A new generation will find inspiration in those who helped give our nation - and our profession - its story.

Brendan J Nelson BMBS

Australian War Memorial, Canberra, ACT

brendan.nelson@awm.gov.au

doi: 10.5694/mjal5.00191

References are available online at www.mja.com.au. 
1 Bean CEW, editor. Official history of Australia in the war of 1914-1918. 12-volume series. Canberra: Australian War Memorial, 1921-1943. 